\title{
REVIEW ON AVIAN HELMINTHOSES DIAGNOSED IN OSUN STATE VETERINARY CLINICS, SOUTHWEST, NIGERIA
}

\author{
${ }^{1 *}$ Ola-Fadunsin, S. D., ${ }^{2}$ Abdullah, D., ${ }^{1}$ Hussain, K., ${ }^{1}$ Rabiu, M., ${ }^{1}$ Ganiyu, I. A., ${ }^{3}$ Karaye, P. G. \\ ${ }^{1}$ Department of Veterinary Parasitology and Entomology, University of Ilorin, PMB 1515, Ilorin, Kwara State, Nigeria. \\ ${ }^{2}$ Department of Animal Production Techniques, Northern Technical University, Iraq. \\ ${ }^{3}$ Department of Veterinary Parasitology and Entomology, University of Jos, Jos, PMB 2084, Plateau State, Nigeria. \\ *E-mail of corresponding author: olashodam2@yahoo.com, Tel. +2349060054605.
}

(Received: $12^{\text {th }}$ June, 2018; Accepted: $17^{\text {th }}$ December, 2018)

\begin{abstract}
Helminthoses exerts negatively on the health and productivity of man and animals. This study was conducted to investigate the incidence and risk factors associated with avian helminthoses in Osun state, Nigeria. Clinical information was retrieved from the record archives of the state veterinary clinics. Case records between January 2006 and December 2015 were examined and relevant data associated with avian helminth disease were extracted. Records on four thousand nine hundred and eighty bird types (2,088 turkeys; 1,476 layers; 384 cockerels; 12 ducks and 1,020 indigenous chickens) were used in the study. Faecal examination for the presence of helminth eggs was carried out by qualified veterinarians and laboratory scientist using the simple floatation method. An overall prevalence of $62.9 \%(3,132 / 4,980)$ was recorded. The year-specific rate for avian helminthoses was highest in $2011(95.5 \%$; 503/528) and lowest in 2007 (2.0\%; 1/48), while the month-specific rate was highest in December $(98.9 \% ; 95 / 96)$ and lowest in October $(15.2 \% ; 84 / 552)$. There was a significantly $(\mathrm{p}<0.05)$ higher prevalence in adult birds compared to young ones, in female compared to male and during the dry season compared to the wet season. Ducks $(91.7 \%$; 11/12) and turkeys $(84.5 \%$; 764/2088) were the bird types with the highest prevalence rate. The high prevalence of avian helminthoses in the study area proves that the disease is endemic. There is need to embark on a radical preventive measure to curtail the disease, for improved productivity in the poultry industry in Osun state and Nigeria.
\end{abstract}

Keyword: Epidemiology, Clinic records, Poultry helminth diseases, Osun state.

\section{INTRODUCTION}

Poultry production has shown to be the most efficient and economic means of meeting the increased demand for animal protein that is associated with the fast growth in the world human population. This is due to the relative small capital required to start off, the ease of feed availability, the fast maturity of the birds and the universal acceptance in the consumption of poultry products (Udoh et al., 2014; Dauda et al., 2016). The poultry industry occupies a vital position in the provision of animal protein (meat and egg) to man and also play an important role in the national economy and socio-economic development of many developing countries of the world been a source of revenue (FOA, 2006, Ola-Fadunsin, 2017).

Furthermore, droppings from poultry are used in growing maggots in fishing industry, and serve as reliable organic manure for cultivated soil (Agbolade et al., 2014). Of the world's poultry population of over eighteen billion (Baboolal et al., 2012), approximately one hundred and ninetytwo million birds made up the poultry population of Nigeria as at 2010 (Akinwumi et al., 2010). In Nigeria, the poultry industry contributes about $25 \%$ to her agricultural GDP, and engages approximately 20 million people through direct and indirect employment (Odeh, 2010; Ngongeh et al., 2014).

Helminthoses is considered to be an important problem of avian species and helminth parasites have been incriminated as a major cause of illhealth and loss of productivity in Africa and different parts of Nigeria (Uhuo et al, 2013). Nematodes, cestodes and trematodes are the three main classes of helminth parasites that infect poultry birds worldwide. Of these, Nematodes constitute the most important class of helminth parasites of poultry both in number of species and the extent of damage they cause (Naphade, 2013). Gastrointestinal helminth infections play a pivotal role in causing hidden economic losses in the production of poultry meat, eggs and its by- 
products. Also, they may have deleterious or debilitating effects on infected birds, especially young birds, causing retarding growth, interfering with healthy development, weaken immune system and making older birds prone to secondary infections (Dauda et al., 2016). Multiple helminthoses is usually seen in poultry that are kept extensively, while heavy infestation is commonly observed in intensively managed stock and this causes weight loss, emaciation, anemia, diarrhea and economic losses such as decreased egg production and also affect other normal activities of the birds resulting to death in severe infections (Hoque et al., 2014).

The prevalence and intensity of helminth infections may be influenced by numerous factors, such as climatic (temperature and humidity), environmental, nutritional factors which may alter the population dynamics of the parasites, resulting in dramatic changes in the prevalence and intensity of helminthic infections (Jegede et al., 2015).

To date there seems to be no report on the prevalence of avian helminthoses in Osun state, southwestern Nigeria. However, studies on the prevalence of avian helminthoses have been conducted in other parts of Nigeria. Ngongeh et al. (2014), Jegede et al. (2015), Dauda et al. (2016) and Afolabi et al. (2016) conducted studies on the prevalence of gastrointestinal helminthes of chickens in Nsukka, Gwagwalada, Jos and Akure respectively. This present investigation was therefore undertaken to provide baseline information on the incidence and risk factors associated with avian helminthoses in Osun state, utilizing a ten year (2006-2015) data from veterinary clinics. This is to assist in the formulation of government policies for a better management, prevention and control measures against avian helminthoses in the state.

\section{MATERIAL AND METHODS}

Study Area

Records for this study were obtained in Osun state, southwest Nigeria, between January 2006 and December 2015. Osun state covers an area of 9,026 square kilometers and is located between latitude $7^{\circ} 30^{\circ} \mathrm{N}$ and longitude $4^{\circ} 30^{\circ} \mathrm{E}$ with an altitude of 246 meters above sea level. The state is characterised by a tropical wet (March - July, September - November) and dry (December February and August) climate with a lowland tropical rain forest vegetation. The state has a mean annual rainfall of between $127.77 \mathrm{~cm}$ and $159.76 \mathrm{~cm}$ and an average annual temperature ranging from $21.1^{\circ} \mathrm{C}$ to $31.9^{\circ} \mathrm{C}$. It records a mean relative humidity of between $58.7 \%$ and $79.6 \%$ (Ola-Fadunsin, 2017).

\section{Study Design and Data Collection}

Clinical records were retrieved from the record archives of the major state veterinary clinics located in Osogbo, Ilesa, Ede and Ikirun. Case records between January 2006 and December 2015 were examined and relevant data associated with avian helminth and non-helminth diseases were extracted. These included information such as the date of presentation to the clinic, the age and sex of the birds and the presence or absence of helminth eggs in the faeces of birds that were brought to the clinic. Faecal examination for the presence of helminth eggs was carried out by qualified veterinarians and laboratory scientist using the simple floatation method as described by Soulsby (Soulsby, 1982).

\section{Data Management and Analysis}

The descriptive statistics was conducted using percentages and tabulations. The prevalence of avian helminthoses was calculated by dividing the number of positive faecal samples by the total number of faecal samples examined and the result expressed in whole numbers and as percentages. The univariate analysis (chi-square) test and odds ratios with its $95 \%$ confidence interval were used to determine the association between each epidemiological factor and the occurrence of helminthoses. The odds ratios were calculated with respect to a reference category as indicated in the respective tables. All statistical tests were conducted using statistical package for social sciences (SPSS) version 22 (SPSS Inc., Chicago). Significant level was set at $\mathrm{p}<0.05$

\section{RESULTS}

The presence of egg of any species of helminth in a faecal sample was considered positive for helminthoses. Of the 4,980 avian species presented and examined in the clinics during the 10 year period, 3,132 were positive for 
helminthoses representing $62.9 \%$ of the population. The yearly distribution of avian helminthoses in Osun state during the ten year period is presented in table 1 . The number of avian helminthoses cases was highest in 2013 (1,092 cases) and lowest in 2007 (1 case) representing $34.9 \%$ and $0.03 \%$ respectively of the total cases of helminthoses. The year-specific rate for avian helminthoses was highest in 2011 $(95.5 \%)$ and lowest in 2007 (2.0\%). However, the odds ratios (ORs) for all the years were significant $(\mathrm{P}<0.05)$ at $95 \%$ confidence interval in relations to the reference year (2015). Generally, there was no defined pattern in the prevalence of helminthoses during the years of study.

Table 1. Yearly Distribution of Avian Helminthoses in Osun State, Nigeria (2006-2015)

\begin{tabular}{llllllll}
\hline Years & $\begin{array}{l}\text { Total Number } \\
\text { of Cases (\%) }\end{array}$ & $\begin{array}{l}\text { Cases of } \\
\text { Helminthoses (\%) }\end{array}$ & $\begin{array}{l}\text { Cases of Non- } \\
\text { Helminthoses (\%) }\end{array}$ & $\begin{array}{l}\text { Year specific } \\
\text { rates (\%) }\end{array}$ & OR & 95 \% CI & $P$ value \\
\hline 2006 & $276(5.5)$ & $252(8.0)$ & $24(1.3)$ & 91.3 & 7.39 & $4.67-12.03$ & $<0.01^{*}$ \\
2007 & $48(1.0)$ & $1(0.03)$ & $47(2.5)$ & 2.0 & 0.02 & $0.001-0.08$ & $<0.01^{*}$ \\
2008 & $216(4.3)$ & $192(6.1)$ & $24(1.3)$ & 88.9 & 5.63 & $3.54-9.21$ & $<0.01^{*}$ \\
2009 & $468(9.4)$ & $312(10.0)$ & $156(8.4)$ & 66.7 & 1.41 & $1.06-1.88$ & $0.02^{*}$ \\
2010 & $300(6.0)$ & $252(8.0)$ & $48(2.6)$ & 84.0 & 3.70 & $2.55-5.42$ & $<0.01^{*}$ \\
2011 & $528(10.6)$ & $503(16.1)$ & $25(1.3)$ & 95.5 & 14.15 & $9.09-22.69$ & $<0.01^{*}$ \\
2012 & $360(7.2)$ & $240(7.7)$ & $120(6.5)$ & 66.7 & 1.41 & $1.04-1.92$ & $0.03^{*}$ \\
2013 & $1176(23.6)$ & $1092(34.9)$ & $84(4.5)$ & 92.9 & 9.16 & $6.74-12.49$ & $<0.01^{*}$ \\
2014 & $1260(25.3)$ & $84(2.7)$ & $1176(63.6)$ & 6.7 & 0.05 & $0.04-0.07$ & $<0.01^{*}$ \\
2015 & $348(7.0)$ & $204(6.5)$ & $144(7.8)$ & 58.6 & 1.00 & & \\
Total & $\mathbf{4 9 8 0 ( 1 0 0 . 0 )}$ & $\mathbf{3 1 3 2}(\mathbf{1 0 0 . 0})$ & $\mathbf{1 8 4 8 ( 1 0 0 . 0 )}$ & $\mathbf{6 2 . 9}$ & & & \\
\hline
\end{tabular}

Reference category, $*$ Significant, OR $=$ Odds Ratio, CI $=$ Confidence Interval

The highest number $(828 ; 26.4 \%)$ of helminthoses cases was recorded in February while the lowest $(25 ; 0.8 \%)$ was in November. The highest month-specific rates of $98.9 \%$ and $86.7 \%$ were observed in December and July with helminthoses cases of $95(3.0 \%)$ and $312(10.0 \%)$ respectively. The lowest month-specific rates of
$15.2 \%$ and $41.7 \%$ were observed in October and November with helminthoses cases of $84(2.7 \%)$ and $25(0.8 \%)$ respectively. The Odds ratio of helminthoses recorded in January to November were significant $(\mathrm{P}<0.05)$ at $95 \%$ Confidence Interval and lower compared to that of December (reference month) (Table 2).

Table 2. Monthly Distribution of Avian Helminthoses in Osun State, Nigeria (2006-2015)

\begin{tabular}{|c|c|c|c|c|c|c|c|}
\hline Months & $\begin{array}{l}\text { Total Number of } \\
\text { Cases }(\%)\end{array}$ & $\begin{array}{l}\text { Cases of } \\
\text { Helminthoses } \quad(\%)\end{array}$ & $\begin{array}{l}\text { Cases of Non - } \\
\text { Helminthoses } \\
(\%)\end{array}$ & $\begin{array}{l}\text { Month } \\
\text { specific rates } \\
(\%)\end{array}$ & OR & $95 \% \mathrm{CI}$ & $P$ value \\
\hline January & $204(4.1)$ & $120(3.8)$ & $84(4.5)$ & 58.8 & 0.02 & $0.001-0.08$ & $<0.01 *$ \\
\hline February & $1020(20.5)$ & $828(26.4)$ & $192(10.4)$ & 81.2 & 0.05 & $0.002-0.23$ & $<0.01 *$ \\
\hline March & $420(8.4)$ & $240(7.7)$ & $180(9.7)$ & 57.1 & 0.01 & $0.001-0.07$ & $<0.01 *$ \\
\hline April & $144(2.9)$ & $120(3.8)$ & $24(1.3)$ & 83.3 & 0.05 & $0.003-0.29$ & $<0.01 *$ \\
\hline May & $528(10.6)$ & $312(10.0)$ & $216(11.7)$ & 59.1 & 0.02 & $0.001-0.08$ & $<0.01 *$ \\
\hline June & $564(11.3)$ & $372(11.9)$ & $192(10.4)$ & 66.0 & 0.02 & $0.001-0.10$ & $<0.01 *$ \\
\hline July & $360(7.2)$ & $312(10.0)$ & $48(2.6)$ & 86.7 & 0.07 & $0.003-0.36$ & $<0.01 *$ \\
\hline August & $372(7.5)$ & $276(8.8)$ & $96(5.2)$ & 74.2 & 0.03 & $0.001-0.16$ & $<0.01 *$ \\
\hline September & $660(13.3)$ & $348(11.1)$ & $312(16.9)$ & 52.7 & 0.01 & $0.001-0.06$ & $<0.01 *$ \\
\hline October & $552(11.1)$ & $84(2.7)$ & $468(25.3)$ & 15.2 & 0.002 & $0.0001-0.01$ & $<0.01 *$ \\
\hline November & $60(1.2)$ & $25(0.8)$ & $35(1.9)$ & 41.7 & 0.01 & $0.0004-0.04$ & $<0.01 *$ \\
\hline December ${ }^{a}$ & $96(1.9)$ & $95(3.0)$ & $1(0.1)$ & 98.9 & 1.00 & & \\
\hline Total & $4980(100.0)$ & $3132(100.0)$ & $1848(100.0)$ & 62.9 & & & \\
\hline
\end{tabular}

${ }^{a}$ Reference category, $*$ Significant, OR $=$ Odds Ratio, $C I=$ Confidence Interval

The risk factors associated with avian helminthoses in Osun state are shown in table 3. Of the 3,048 young birds examined, 1,608 were positive, representing a prevalence of $52.8 \%$, while 1,524 adult birds were positive, representing $78.9 \%$ of the total 1,932 . The infection rate of helminthoses was 3.33 times more in adult birds compared to young birds. Based on sex, female birds were 1.59 times more likely to be infected with helminthoses compared to male birds. Of the 2,592 female birds examined 1,764 (68.1\%) were positive, while 1,368 representing $57.3 \%$ of 
the total 2,388 male birds were diagnosed for helminthoses. More number of avian species was presented to the clinics during the wet season compared to the dry season. Of the 3,228 cases presented during the wet season, $1,788(55.4 \%)$ were positive for helminthoses, compared to the 1,752 cases presented during the dry season where
$1,344(76.7 \%)$ were positive. The infection rate of helminthoses was 2.65 times more during the dry season compared to the wet season. All the epidemiological factors were significantly $(\mathrm{P}<0.05)$ associated with the occurrence of avian helminthoses.

Table 3. Risk factors Associated with Avian Helminthoses in Osun State, Nigeria (2006-2015)

\begin{tabular}{|c|c|c|c|c|c|c|}
\hline Risk factors & $\begin{array}{l}\text { Total Number } \\
\text { of Cases }\end{array}$ & $\begin{array}{l}\text { Cases of } \\
\text { Helminthoses } \\
(\%)\end{array}$ & $\begin{array}{l}\text { Cases of Non - } \\
\text { Helminthoses } \\
(\%)\end{array}$ & OR & $95 \%$ CI & $P$ value \\
\hline \multicolumn{7}{|l|}{ Age } \\
\hline Young & 3048 & $1608(52.8)$ & $1440(47.2)$ & 0.30 & $0.26-0.34$ & $<0.01^{*}$ \\
\hline Adult ${ }^{a}$ & 1932 & $1524(78.9)$ & 408 (21.1) & 1.00 & & \\
\hline \multicolumn{7}{|l|}{ Sex } \\
\hline Female & 2592 & 1764 (68.1) & 828 (31.9) & 1.59 & $1.42-1.78$ & $<0.01 *$ \\
\hline Male $^{a}$ & 2388 & $1368(57.3)$ & $1020(42.7)$ & 1.00 & & \\
\hline \multicolumn{7}{|l|}{ Season } \\
\hline Dry & 1752 & 1344 (76.7) & 408 (23.3) & 2.65 & $2.33-3.02$ & $<0.01 *$ \\
\hline Wet ${ }^{a}$ & 3228 & $1788(55.4)$ & $1440(44.6)$ & 1.00 & & \\
\hline
\end{tabular}

${ }^{a}$ Reference category, $*$ Significant, OR $=$ Odds Ratio, CI = Confidence Interval

The highest prevalence of helminthoses was recorded in ducks $(91.7 \%)$ followed by turkeys $(84.5 \%)$, layers $(61.8 \%)$ and indigenous chickens $(36.6 \%)$. Cockerels were the least prevalent for the disease condition with $18.8 \%$ prevalence. Helminthoses was 19.08, 9.44 and 2.81 times more likely to occur in ducks, turkeys, layers respectively compared to indigenous chickens. However helminthoses is 2.25 times more likely to occur in indigenous chickens compared to cockerels. The Odds ratio of all the bird types were significant $\mathrm{P}<0.05$ )at $95 \%$ Confidence Interval compared to indigenous chickens (Table 4).

Table 4. Distribution of Aavian Helminthoses among Bird Types in Osun State, Nigeria (2006-2015)

\begin{tabular}{lllllll}
\hline Type of bird & $\begin{array}{l}\text { Total Number } \\
\text { of Cases }\end{array}$ & $\begin{array}{l}\text { Cases of } \\
\text { Helminthoses } \\
(\%)\end{array}$ & $\begin{array}{l}\text { Cases of Non - } \\
\text { Helminthoses }(\%)\end{array}$ & OR & 95\% CI & P value \\
\hline Turkeys & 2088 & $1764(84.5)$ & $324(15.5)$ & 9.44 & $7.94-11.24$ & $<0.01^{*}$ \\
Layers & 1476 & $912(61.8)$ & $564(38.2)$ & 2.81 & $2.38-3.31$ & $<0.01^{*}$ \\
Cockerels & 384 & $72(18.8)$ & $312(81.3)$ & 0.40 & $0.30-0.53$ & $<0.01^{*}$ \\
$\begin{array}{l}\text { Ducks } \\
\begin{array}{l}\text { Indigenous } \\
\text { chickens }\end{array}\end{array}$ & 12 & $11(91.7)$ & $1(8.3)$ & 19.08 & $2.45-148.40$ & $<0.01^{*}$ \\
\hline
\end{tabular}

${ }^{a}$ Reference category, $*$ Significant, OR $=$ Odds Ratio, $\mathrm{CI}=$ Confidence Interval

\section{DISCUSSION}

Avian helminthoses is a big constraint in the poultry industry, and it is characterised with retarded growth, delayed fertility and productivity and even death (Agbolade et al., 2014). Despite this, there seems to be no report on the prevalence of avian helminthoses in Osun state. Interestingly, an overall prevalence of $62.9 \%$ was recorded in this study, suggesting that helminthoses is an important disease among avian species in the state. Within Nigeria, dispersing prevalence of $100.0 \%$,
$86.0 \%, 81.3 \%, 27.9 \%$ and $11.9 \%$ has been reported by Uhuo et al. (2013), Attah et al. (2013), Adang et al. (2014), Jegede et al. (2015) and Afolabi et al. (2016) in Abakaliki, Sokoto, Gombe, Gwagwalada and Akure respectively. In other parts of the world, prevalence rate of $7.3 \%$ has been reported in Iran (Badparva et al., 2015), $10.5 \%$ in Trinidad (Baboolal et al., 2012), $51.7 \%$ in India (Naphade, 2013) and $100.0 \%$ in Zambia (Nalubamba et al., 2015). The differences in the prevalence rate reported by the above researchers 
compared to that reported in this study can be attributed to the fact that more avian types were included in this study as against the above mentioned studies where restrictions were made to one or fewer avian types ranging from broilers, layers, ducks, guinea fowls and local (indigenous) chickens. Also, factors such as sampling periods, sample size, study design, geographical area, and climatic conditions could have resulted to the disparity in the reported prevalence.

The undefined monthly and yearly pattern in the prevalence of avian helminthoses in this study could be attributed to the inability of poultry farmers to consistently and properly maintain a standard biosecurity and hygienic practice in their farms. Also, the off and on participation of farmers in the poultry business, the previous Avian Influenza outbreak in Nigeria and the increased sensitization of poultry farmers to report clinical cases of poultry diseases to veterinary hospitals and clinics could have contributed to this undefined monthly and yearly pattern of distribution.

Sex is an important epidemiological index associated with the prevalence of avian helminthoses as the disease has no sexual bias (Attah et al., 2013; Jegede et al., 2015). Supporting this report, this investigation has brought to light the information that both sexes were burdened with helminthoses with female having a significantly higher prevalence rate. In line with this finding, Uhuo et al. (2013) and Opara et al. (2014) reported a higher prevalence of helminthoses in female birds compared to their male counterpart. In contrast, Dauda et al. (2016) and Attah et al. (2013) documented that male birds are more prone to helminthoses compared to female. The higher prevalence of helminthoses recorded in female compared to male may be attributed to stress associated with laying and brooding, and the more frequent scratching of the ground (by birds raised in free range) to find food for their chicks and in the process picks up helminth eggs and infected intermediate hosts of helminths such as earthworms and beetles. Also the fact that hens catches prey such as flies, grasshoppers and cockroaches for their chicks may have resulted to the higher prevalence recorded in female. Earthworms, beetles, flies, grasshoppers and cockroaches are intermediate host of some helminth parasites (Radfar et al., 2012).

This study also reports a higher prevalence of helminthoses in adult birds compared to young birds. Radfar et al. (2012) reported similar findings in their work carried out in Iran. They argued that the higher prevalence in adults might be related to cohort effect. Dauda et al. (2016) reported a contrasting finding in their work carried out in Jos. In addition to the submission of Radfar et al. (2012), the high prevalence seen in adult birds may be associated with the fact that they scavenge more than young birds and so increases their chances of been infected. In Nigeria, young birds are mainly kept intensively for the fear of predators, as such reducing their chances of picking up helminth eggs and its intermediate hosts. Afolabi et al. (2016) reported the lowest prevalence of avian intestinal parasites in domestic birds raised intensively compared to those raised semi-intensively and extensively.

Higher prevalence of helminthoses was recorded during the dry season as against the wet season. In line with this finding, Naphade (2013) reported that most number of broiler birds was infected with gastrointestinal helminths during the summer compared to the raining and winter seasons. The higher prevalence recorded during the dry season may be attributed to the climatic characteristics of the dry season (high temperature and low humidity) which favours the survival of many insects that may serve as vectors for helminthic infection. Also, the nature of this study (retrospective study) may have influenced this finding as birds may be infected with helminths during the wet season, and were presented to the veterinary clinics during the dry season, thereby increases the dry season prevalence.

Ducks had the highest helminth infection rate (91.7\%) compared with the other bird types, turkeys and layers also had alarming prevalence rate of $84.5 \%$ and $61.8 \%$ respectively. Previous researchers in Nigeria had reported helminthoses prevalence in layers as $41.4 \%$ (Ngongeh et al., 2014), ducks as $4.7 \%$ as (Adang et al., 2014), turkeys as 68.3\% (Dauda et al., 2016) and 44.3\% in 
indigenous chickens (Jegede et al., 2015). Helminth prevalence of $52.0 \%$ has been reported in ducks in Tanzania (Muhairwa et al., 2007), $89.5 \%$ in scavenging chickens in Ethiopia (Hussen et al., 2012) and 58.8\% among indigenous birds in India (Hembram et al., 2015). Several factors such as sampling periods, sample size, study design, geographical area, and climatic conditions affects the prevalence and epidemiology of animal diseases (Jegede et al., 2015; Ola-Fadunsin, 2017), and could have resulted in the disparity in the reported prevalence. The highest prevalence of helminthoses recorded among ducks compared to the other bird types may be associated with the nature of ducks, whereby they usually submerge their entire bill in water/mud and as such may pick up helminth eggs and/or their intermediate host (e.g. earthworm).

\section{CONCLUSION}

The overall $62.9 \%$ prevalence of helminthoses among avian species in the studied area proves that the disease condition is endemic in the state. Age, sex, season and difference in bird types are the risk factors associated with the incidence of avian helminthoses in Osun state. The endemicity of the condition translates to a great economic setback to the poultry industry by causing illhealth, loss of productivity and even death to poultry species. This will lead to unemployment and a depletion of poultry protein source for man. Strict biosecurity, good sanitary measures and regular deworming of birds will serve as a control and preventive measure against avian helminthoses.

\section{ACKNOWLEDGMENTS}

Special thanks are due to Dr. Olubukola Aluko, the director, and all the staff of Osun state veterinary services for granting access to the records.

\section{REFERENCES}

Adang, K.L., Asher, R. and Abba, R. 2014. Gastrointestinal helminths of domestic chickens Gallus gallus domestica and ducks Anas platyrhynchos slaughtered at Gombe main market, Gombe State, Nigeria. Asian Journal of Poultry Science, 8(2): 32-40.

Afolabi, O.J., Simon-Oke, I.A. and Olasunkanmi, A.O. 2016. Intestinal parasites of domestic chicken (Gallus gallus domesticus) in Akure, Nigeria. Journal of Biomedicine, 1(4): 1-4.

Agbolade, O.M., Arosoye, A.S., Akajiugo, E.C., Akinyemi, H.A., Owolowo, A.M., Ariba, O., and Jonathan, K.A. 2014. Gastrointestinal parasites of domestic fowls from Ijebu North, southwestern Nigeria. Basic Research Journal of Agricultural Science and Review, 3(7): 6064.

Akinwumi, J., Okike, I. and Rich, K.M. 2010. Analyses of the poultry value chain and its linkages and interactions with HPAI risk factors in Nigeria. DFID, FAO, RVC, Rural Development Research Consortium, International Food Policy Research Institute, International Livestock Research Institute, pp. 23-36

Attah, D.D., Danladi, Y.K., Abdullahi, K. and Ibrahim, S. 2013. A Survey of gastrointestinal helminthes of chickens and guinea fowls slaughtered at Sokoto, Nigeria. Equity Journal of Science and Technology, 1(1): 1-5.

Baboolal, V., Suratsingh, V., Gyan, L., Brown, G., Offiah, N.V., Adesiyun, A.A. and Basu, A.K. 2012. The prevalence of intestinal helminths in broiler chickens in Trinidad. Veterinarski Arhiv, 82(6): 591-597.

Badparva, E., Ezatpour, B., Azami, M. and Badparva, M. 2015. First report of birds infection by intestinal parasites in Khorramabad, west Iran. Journal of Parasitic Diseases, 39(4): 720-724.

Dauda, J., Lawal, J.R., Bello, A.M., Mustapha, M., Ndahi, J.J. and Biu A.A. 2016. Survey on prevalence of gastrointestinal nematodes and associated risk factors in domestic turkeys (Meleagris gallopavo) slaughtered in poultry markets in Bukuru - Jos, Plateau state, Nigeria. International Journal of Innovative Agriculture \& Biology Research, 4(4): 27-36.

Food and Agricultural Organization (FOA), 2006. High Bird Flu in Africa after outbreak in Nigeria, Available from: http:llwww.Fao.Org/newsoom/en/news / 2006/1000226/index. html. Assessed Aug 15, 2017.

Hembram, A., Panda, M.R., Mohanty, B.N., Pradhan, C.R., Dehuri, M., Sahu, A. and 
Behera, M. 2015. Prevalence of gastrointestinal helminths in Banaraja fowls reared in semi-intensive system of management in Mayurbhanj district of Odisha. Veterinary World, 8(6): 723-726.

Hoque, M.A., Hassan, M.M., Haque, E., Shaikat, A.H., Khan, S.A., Alim, A., Skerrat, L.F., Islam, A., Tun, H.M., Dissanayake, R., Day, T.K., Debnath, N.C. and Yamage, M. 2014. A survey of gastro-intestinal parasitic infection in domestic and wild birds in Chittagong and Greater Sylhet, Bangladesh. Preventive Veterinary Medicine, 117: 305-312.

Hussen, H., Chaka, H., Deneke, Y. and Bitew, M. 2012. Gastrointestinal helminths are highly prevalent in scavenging chickens of selective districts of Eastern Shewa zone, Ethiopia. Pakistan Journal of Biological Sciences, 15(6): 284-289.

Jegede, O.C., Asadu, I.A., Opara, M., Obeta, S.S. and Olayemi, D.O. 2015. Gastrointestinal parasitism in local and exotic breeds of chickens reared in Gwagwalada Guinea Savannah zone of Nigeria. Sokoto Journal Veterinary Science, 13(3): 25-30.

Muhairwa, A.P., Msoffe, P.L., Ramadhani, S., Mollel, E.L., Mtambo, M.M.A. and Kassuku, A.A. 2007. Prevalence of gastro-intestinal helminths in free-range ducks in Morogoro municipality, Tanzania. Livestock Research for Rural Development. Available from https://www.lrrd.org/lrrd19/4/muha19 048.htm. Assessed Aug 31, 2017

Nalubamba, K.S., Bwalya, E.C., Mudenda, N.B., Munangandu, H.M., Munyeme, M. and Squarre D. 2015. Prevalence and burden of gastrointestinal helminths in wild and domestic guinea fowls (Numida meleagris) in the southern province of Zambia. Asian Pacific Journal of Tropical Biomedicine, 5(8): 663-670.

Naphade, S.T. 2013. Studies on the prevalence of helminthic infection in broiler poultry birds from Marathwada region, (MS) India. Science Research Reporter, 3(2): 233-238.

Ngongeh, L.A., Chiejina, S.N. and Lawal, A.I.
2014. Prevalence of gastrointestinal helminth infections in slaughtered chickens reared in the Nsukka area of Enugu State, Nigeria. IOSR Journal of Agriculture and Veterinary Science, 7(11): 51-54.

Odeh, O. 2010. Nigeria: Ban on Chicken Import Creates $20 \mathrm{~m}$ Jobs. 0. From All Africa: Available from http://allafrica. com/stories/201011170218.html. Assessed Nov 13,2017

Ola-Fadunsin, S.D. 2017. Investigations on the occurrence and associated risk factors of avian coccidiosis in Osun state, southwestern Nigeria. Journal of Parasitology Research, Article ID 9264191 pp. 1-6.

Opara, M.N., Osowa, D.K. and Maxwell, J.A. 2014. Blood and gastrointestinal parasites of chickens and turkeys reared in the tropical rainforest zone of southeastern Nigeria. Open Journal of Veterinary Medicine, 4:308-313.

Radfar, M.H., Khedri, J., Adinehbeigi, K., Nabavi, R. and Rahmani, K. 2012. Prevalence of parasites and associated risk factors in domestic pigeons (Columba livia domestica) and free-range backyard chickens of Sistan region, east of Iran. Journal of Parasitic Diseases, 36(2): 220225.

Soulsby, E.J.L. 1982. Helminths, Arthropods and Protozoa of Domestic Animals. 7th edn. Bailliere TIndall Publishers London, pp. 809.

Udoh, N.A, Luka, S.A. and Patrick, A.A. 2014. Prevalence of Gastrointestinal Parasites of Domestic Turkey (Meleagris Gallopavo) Linnaeus, (1758) Slaughtered in Kaduna Metropolis, Kaduna State, Nigeria. Journal of Natural Sciences Research, 4(17): 105-109.

Uhuo, A.C., Okafor, F.C., Odikamnoro, O.O., Onwe, C.S., Abarike, M.C. and Elom, J.N. 2013. Common gastrointestinal parasites of local chicken (gallus domesticus) slaughtered in some selected eatery centres in Abakaliki, Ebonyi State: Implication for meat quality. International 